\title{
UDC: 635.649.631.234:631.86
}

\section{PECULIARITIES OF APPLICATION OF MICORIZE PREPARATIONS FOR THE GROWING OF SWEET PEPPER IN A GREENHOUSE}

\author{
Vdovenko S.A. \\ Vinnytsia National Agrarian University \\ Sonyachna str., 3, Vinnytsia, Ukraine, 28003 \\ E-mail: sloi@i.ua \\ https://doi.org/10.32717/0131-0062-2019-66-39-46
}

In order to study the effect of mycorrhizal preparations on the performance of sweet pepper in film greenhouse conditions, the experiment scheme included variants where the mycorrhizal preparations of the BTU Center were used, which treated the root system of sweet pepper seedlings before planting at a permanent place of vegetation. Seedlings were treated with the drugs Melanoriz and Mikofrend separately at a dose of 0.5 and 1.01 per 1000 units. seedlings. Seedlings whose root system was not treated with mycorrhizal preparations served as control. Seedlings of Claudio sweet pepper and Nikita $\mathrm{F}_{1}$ hybrid were planted in the CIMET film greenhouse in the second decade of April. Treatment of plants with mycorrhizal preparations has a positive effect on both the plant and the growth processes of the root system. The formation of ectomycorrhiza is determined as a result of the use of Melanorizo or Mikofrend preparations. The root system itself, at the end of the vegetation of the plant, was obsessed with the mycelium of the fungus, which protected it from soil moisture and the development of rot, especially root. With the use of Melanorizo and Mikofrend dose of 1.01 per 1000 units. seedlings during the cultivation of Nikita $F_{1}$ hybrid start budding, flowering and fruiting were observed earlier 2 days from the control plants. A similar positive effect of the preparations was obtained during the cultivation of Claudio, regardless of the dose of the preparation. The difference in the beginning of these phases of seedling development was 3-5 days, and the use of drugs provided a longer growing season. From the use of Melanoriz dose of 0.51 or Mikofrend dose of 1.01 per 1000 units seedlings during the cultivation of Claudio variety received the largest number of fruits, their total number increases by $33 \%$. The weight of the sweet pepper fruit varies depending on the dose of the preparation and ranges from75 $\mathrm{g}$ to 190 g. For the use of Melanoriz with a dose of 0,5 or 1,0 1 per 1000 units. seedlings, during cultivation of Nikita $\mathrm{F}_{1}$ hybrid or Claudio variety, the highest fruit weight index was $160-190 \mathrm{~g}$ (in the case of Nikita $\mathrm{F}_{1}$ hybrid) and 150-170 g (in the case of Claudio variety). The diameter of the fruit, from the use of mycorrhizal preparations varied within wide enough limits: from $4.5 \mathrm{~cm}$ to $7.0 \mathrm{~cm}$ : the highest values were characterized by plants of the Claudio variety for the use of Melanoriz with a dose of 0.51 per 1000 units. seedlings or Mikofrend dose of 1.01 per 1000 units seedlings. In these variants, the diameter of the fetus was $7.5 \mathrm{~cm}$ and 7.0 $\mathrm{cm}$. With the use of mycorrhizal preparations Melanoriz or Mikofrend, the yield of bell peppers can increase to $2.5 \mathrm{~kg} / \mathrm{m}^{2}$. The higher yields are characterized by the plants of the Nikita F1 hybrid, and the smaller one by the Coaudio variety. Use of Melanorize at a dose of 0.5 and 1.01 per 1000 units seedlings provide in the yield increase to $2.2-2.5 \mathrm{~kg} / \mathrm{m}^{2}$, which helps in obtaining profitability at the level of $98-101 \%$.

Key words: bell pepper, mycorrhiza, drug, dose, biometrics, mass, yield, profit.

\section{ОСОБЛИВОСТІ ЗАСТОСУВАННЯ МІКОРИЗНИХ ПРЕПАРАТІВ ЗА ВИРОЩУВАННЯ ПЕР- ЦЮ СОЛОДКОГО В ЗАКРИТОМУ ГРУНТІ}

\section{Вдовенко С. А.}

Вінницький національний аграрний університет

вул. Сонячна, 3, м. Вінниця, Україна, 28003

E-mail: sloi@i.ua

3 метою вивчення впливу мікоризних препаратів на продуктивність перцю солодкого в умовах плівкової теплиці до схеми досліду входили варіанти, де застосовували мікоризні препарати компанії БТУ-центр, якими оброблено кореневу систему розсади перцю солодкого перед висаджуванням на постійне місце вегетації. Розсаду обробляли препаратами Меланоріз та Мікофренд окремо дозою 0,5 
та 1,0 л на 1000 од. розсади. Контролем слугувала розсада, кореневу систему якої не обробляли мікоризними препаратами. Розсаду сорту перцю солодкого Клаудіо та гібрида Нікіта $\mathrm{F}_{1}$ висаджували у плівковій теплиці ЦІМЕТ в II декаді квітня. Обробка рослин мікоризними препаратами позитивно впливає як на рослину, так і на ростові процеси кореневої системи. У результаті застосування препаратів Меланоріз чи Мікофренд визначено формування ектомікоризи. Сама коренева система в кінці вегетації рослини була опанована міцелієм гриба, який захищав ії від перезволоження грунту та розвитку гнилей, особливо кореневої. За використання Меланорізу та Мікофренду дозою 1,0 л на 1000 од. розсади під час вирощування гібрида Нікіта $\mathrm{F}_{1}$ початок бутонізації, цвітіння та плодоношення спостерігали раніше на 2 доби від рослин контрольного варіанта. Аналогічний позитивний вплив препаратів отримано й під час вирощування сорту Клаудіо (незалежно від дози препарату). Різниця початку зазначених фаз розвитку розсади складала 3-5 діб, а застосування препаратів забезпечило більш тривалий період вегетації. Від використання Меланорізу дозою 0,5 л чи Мікофренду дозою 1,0 л на 1000 од. розсади під час вирощування сорту Клаудіо отримано найбільшу кількість плодів, загальна їх кількість збільшується на 33 \%. Маса плода перцю солодкого змінюється залежно від дози препарату і коливається від 75 г до 190 г. За використання Меланорізу дозою 0,5 чи 1,0 л на 1000 од. розсади, під час вирощування гібрида Нікіта $F_{1}$ чи сорту Клаудіо показник маси плода був найбільшим і становив 160-190 г (у випадку гібрида Нікіта $F_{1}$ ) та 150-170 г (у випадку сорту Клаудіо). Діаметр плода, від застосування мікоризних препаратів варіював у досить широких межах: від 4,5 см до 7,0 см: найбільшим його значенням характеризувалися рослини сорту Клаудіо за використання Меланорізу дозою 0,5 л на 1000 од. розсади чи Мікофренду дозою 1,0 л на 1000 од. розсади. У вказаних варіантах діаметр плода становив 7,5 cм та 7,0 см. За використання мікоризоутворюючих препаратів Меланоріз чи Мікофренд урожайність перцю солодкого може збільшуватися до 2,5 кг $\mathrm{M}^{2}$. Більшою врожайністю характеризуються рослини гібрида Нікіта $F_{1}$, а меншою - сорт Коаудіо. Використання Меланорізу дозою 0,5 та 1,0 л на 1000 од. розсади забезпечило збільшення врожайності до 2,2-2,5

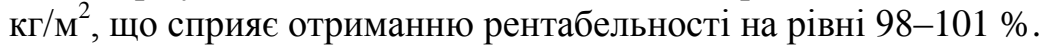

Ключові слова: перець солодкий, мікориза, препарат, доза, біометрія, маса, урожайність, прибуток

Постановка проблеми. Перець солодкий і продукти його переробки користуються великим попитом завдяки високим смаковим та харчовим якостям. Використовують плоди перцю солодкого як у технічній, так і в біологічній стиглості, їх споживають свіжими під час приготування салатів, у жареному, тушкованому, фаршированому й маринованому вигляді. Плоди перцю солодкого використовують для приготування багатьох видів консервів і різних соусів. Цінність перцю зумовлена вмістом у плодах необхідних для людини органічних кислот, солей, азотистих речовин, цукрів i, особливо, вітамінів. Плоди також багаті на Р-активні речовини (70-380 мг в 100 г сирої маси), містять значну кількість каротину, вітамінів групи В, фолієвої та нікотинової кислот. Під час консервування вміст вітамінів у плодах перцю зменшується на 40-55 \%, а вміст сухої речовини становить 6-12\%. Специфічний аромат перцю зумовлено вмістом летких ефірних олій, концентрація яких коливається від 0,1 до 1,25 \% сухої речовини (Dudnyk S.P., Yelahin, V.D., 1989).

Виробництво перцю солодкого в Україні становить понад 100 тис. т на рік, проте потреба в цій продукції щороку зростає. А тому нині поставлено завдання щодо повного забезпечення потреби промисловості й населення в сезонний та позасезонний період. Досвід передових господарств свідчить, що майже в усіх зонах країни можна одержувати високі й сталі врожаї перцю солодкого за впровадження досягнень науки й передового досвіду (Barabash, O.Y., 2002, Hil, L.S., Pashkovskyi, 2008).

Аналіз останніх досліджень. Враховуючи ситуацію на валютному ринку та попит, що зростає на продукцію перцю солодкого, можна 3 упевненістю вважати, що його виробництво $€$ більш прибутковим, а вітчизняна продукція відрізняється від імпортної ціною. Проте, для отримання високих показників неодмінною передумовою $є$ іiі якість, яку забезпечують високопродуктивні сорти та гібриди, що адаптовані до умов вирощування в Україні й максимально відповідають вимогам ринку (Ermolenko, O.V., Nerodenko, O.M., 2008). Зоною основного вирощування перцю солодкого в умовах України $\epsilon$ Степ. На іншій території України перець вирощують на обмежених площах 3 отриманням екологічно безпечної продукції, однак наукові дослідження над культурою перцю солодкого проводили в обмеженій кількості, а тому поста- 
ла необхідність розгляду основних питань технології вирощування 3 використанням біопрепаратів (Vdovenko, S.A., 2016; Vdovenko, S.A. Davymoka, O.V., 2016).

Під час вирощування перцю солодкого в умовах відкритого й закритого грунту рослини можуть бути пошкоджені різними видами захворювань, серед яких небезпечними вважають кореневу й сіру гниль, а також склеротинію (Ermolenko, O.V., Nerodenko, O.M., 2008). Погана структура грунту, слабкий дренаж, недостатнє вентилювання й неефективний температурний контроль створюють більш сприятливі умови для поширення хвороб. Для боротьби 3 ними широко застосовують стерилізацію субстратів і теплиць, проте це є досить затратні заходи (Pysarenko, V.M., 2000). Нині вже не слід доводити доцільність використання біологічних засобів для захисту сільськогосподарських рослин. До основи біологічних препаратів входять живі мікроорганізми або продукти їх життєдіяльності. Штучне внесення їх до агроекосистеми супроводжується зменшенням кількості патогенів у середовищі, як це відбувається під час природних фітофагів (Anishyn, L.A., 2004). Біологічний метод захисту рослин є основою стратегічного еколого-біологічного контролю шкідливих організмів за вирощування сільськогосподарських рослин. Розвиток науково обгрунтованого біологічного захисту рослин у нашій країні розпочався у минулому столітті, пріоритет у галузі застосування мікроорганізмів для боротьби зі шкідниками й хворобами належить українським ученим та вітчизняним виробникам. Біопрепарати застосовують так само, як i фунгіциди, інсектициди та протруйники. Особливого поширення біологічний метод боротьби в Україні набув у другій половині минулого століття (Pysarenko, V.M., 2000).

Застосування біопрепаратів має низку переваг перед хімічними засобами захисту рослин, а саме: високу біологічну активність стосовно шкодочинних мікроорганізмів; загибель шкідливих мікроорганізмів у наступних поколіннях; вибірковість, безпечність для ентомофагів та комах-запилювачів; безпечність для теплокровних тварин і людини; відсутність фітотоксичності та впливу на смакові якості продукції; малий термін очікування; можливість застосування в різні фази вегетації рослин та уникнення ризику нагромадження токсичних речовин (Antoniak, H.L., Kalynets-Mamchur, Z.I., 2013). Проте, біологічні препарати, як правило, діють повільніше, ніж хімічні. Так, загибель мікроор- ганізмів під впливом бактеріальних препаратів на основі кристалоутворювальних бактерій настає на третю - п’яту добу після обробки, а прояв максимальної дії - на десяту - одинадцяту. Після їх застосування шкодочинні організми швидко припиняють живлення, а інтенсивність пошкодження рослин значно знижується (Didovska, T.P., 2008).

Використання біологічних препаратів для захисту рослин є безпечним ще й тому, що кількість мікроорганізмів саморегулюється. Якщо на початку розробки перших біологічних засобів захисту рослин переважали препарати проти фітофагів, то останніми роками асортимент біопрепаратів щоразу істотно розширюється: розроблено нові препарати, які стримують розвиток збудників хвороб і підвищують урожайність рослин. Перспективними є біологічні препарати комплексної дії, які забезпечують захист культур від двох і більше видів шкідливих організмів (Kostikov, I.Y., Dzhahan, V.V., 2004; Nechytailo, V.A., Kucheriava, L.F., 2001; Tykhonenko, D.H., Dehtiarov, V.V., 2003). Одним 3 елементів технології, що передбачає одержання безпечної продукції, вважають використання мікоризних препаратів. Згідно 3 даними Kamieński F. тa Frank A.B. (Frank, A.B., 1885; Kamieński, 1882) мікориза - це симбіотичне співжиття гриба 3 рослиною. Таке співжиття реалізується через кореневу систему рослини, у взаємодії міцелій гриба колонізує корені рослини, утворюючи при цьому внутрішньо- або зовнішньоклітинну мікоризу. Розрізняють три типи мікоризи: ектотрофну (зовнішню), ендотрофну (внутрішню) та екто-ендотрофну (змішану). За формування ектотрофної мікоризи гіфи гриба опановують кореневу систему рослини ззовні, утворюючи товстий і щільний чохлик (гіфову мантію). За ендотрофної мікоризи гіфи гриба проникають у клітини корової паренхіми й розвиваються всередині клітин у вигляді клубочків, а у випадку, коли гіфи гриба частково проникають у клітини корової паренхіми, таку мікоризу вважають ектоендотрофною (Smyt, S.E., Ryd, D.Dzh., 2012; Heckman, D.S. et al., 2001; Molina, R., Massicotte, H., 1992).

Мета статті: обгрунтування застосування мікоризних препаратів та їх вплив на продуктивність перцю солодкого в умовах плівкової теплиці.

Матеріал та методика досліджень. Вирощування перцю солодкого відбувалось у плівковій теплиці Вінницького НАУ впродовж 
2018-2019 рр. У дослідженнях використано два види мікоризних препарати компанії БТУцентр, якими оброблено кореневу систему розсади перцю солодкого перед висаджуванням на постійне місце вегетації. Розсаду обробляли препаратами Меланоріз та Мікофренд окремо дозою 0,5 та 1,0 л на 1000 од. розсади. Контролем слугувала розсада, кореневу систему якої не обробляли мікоризними препаратами. Розсаду сорту перцю солодкого Клаудіо та гібрида Нікіта $\mathrm{F}_{1}$ висаджували у плівковій теплиці ЦІMET в II декаді квітня, варіанти досліду розміщували методом рендомізованих блоків у триразовій повторності.

Під час проведення досліду визначали початок проходження фаз росту та розвитку рослини, а саме: дата появи сходів, формування першого та четвертого і п'ятого листка, початок бутонізації, масове цвітіння, початок плодоношення, кінець вегетації. Також проводили біометричні визначення кількості, маси і діаметра плодів, висоту рослини та величину врожаю кожного варіанта. Методом спостереження відслідковували початок фенологічних фаз росту й розвитку рослини, а для визначення біометричних показників застосовували лабораторний метод (Dospekhov, B.A., 1985). Плоди збирали в біологічній стиглості згідно з вимогами стандарту (DSTU 3246-95). Одержане значення врожайності кожного варіанта перераховували в показник кг $/ \mathrm{M}^{2}$.

Виклад основного матеріалу. Сходи рослини перцю солодкого спостерігали вже на 5 добу після висіву насіння. Сіянці досліджуваних сортів формували на поверхні грунту типові сім'ядольні листочки, які не зазнали ушкоджень шкодочинними організмами, а формування першого та четвертого й п'ятого листків були майже однаковими у часі в усіх досліджених рослин. Зазначені фази у рослини спостерігали на 19 та 60 доби після появи сходів. Однак надалі період їх росту й розвитку різнився й залежав від дози застосованого біопрепарату. Так, за використання Меланорізу та Мікофренду дозою 1,0 л на 1000 од. розсади під час вирощування гібрида Нікіта $F_{1}$ початок бутонізації, цвітіння та плодоношення спостерігали раніше на 2 доби від рослин контрольного варіанта. Аналогічний позитивний вплив препаратів отримано й під час вирощування сорту Клаудіо, незалежно від дози препарату. Різниця в початку зазначених фаз розвитку розсади складала 3-5 діб, а застосування препаратів забезпечило більш тривалий період вегетації.
Обробка рослин мікоризними препаратами позитивно впливає як на рослину, так і на ростові процеси кореневої системи. У результаті застосування препаратів Меланорізу чи Мікофренду визначено формування ектомікоризи. Сама коренева система в кінці вегетації рослини була опанована міцелієм гриба, який захищав ii від перезволоження грунту та розвитку гнилей, особливо кореневої, на ії поверхні спостерігали товстий чохлик, що підтверджує думку Redecker D., Schüßler, A., Taylor T.N. (Redecker, D. et al., 2000; Schüßle,, A., 2001; Taylor, T.N., 1995). Одночасно мікориза забезпечила зменшення стресу у рослини під час висаджування на постійне місце вегетації й створила захисний бар'єр.

У результаті мікоризації кореневої системи показники біометрії перцю солодкого не були сталими й змінювалися залежно від дози препарату як у бік збільшення, так і в бік зменшення, що частково підтверджено дослідженнями Вдовенка С.А., Давимоки О.В., Мудріцької Л.М. (Vdovenko, S.A., 2016; Vdovenko, S.A. Davymoka, 2016). Проте продуктовий орган відповідав сортовим особливостям, плоди мали типове забарвлення, не були пошкоджені шкодочинними організмами, їх збирали в біологічній стиглості. Залежало від сортових особливостей перцю солодкого та дози застосованого препарату кількість плодів на рослині, загальна величина їх у досліді коливалася від 2 до 4 шт. Найбільшу кількість отримано у варіанті, де застосовували Меланоріз дозою 0,5 л на 1000 од. розсади чи Мікофренд дозою 1,0 л на 1000 од. розсади під час вирощування сорту Клаудіо. У вказаних варіантах загальна кількість плодів становила 4 шт. і перевищувала кількість плодів контрольного варіанта на $33 \%$. В інших варіантах досліду кількість плодів або була аналогічною до контролю, або їх значення було меншим. Так під час вирощування гібрида Нiкіта $\mathrm{F}_{1}$ застосування Мікофренду дозою 1,0 л на 1000 од. розсади забезпечило формування лише 2 плодів на рослині, що було менше за контрольний варіант на 50 \% (табл. 1). 
Таблиця 1 - Біометричні показники рослини залежно від дози препарату (середнє за 2018-2019 рр.)

\begin{tabular}{|c|l|c|c|c|c|c|}
\hline \multirow{3}{*}{ Сорт } & \multicolumn{1}{|c|}{ Біопрепарат } & $\begin{array}{c}\text { Доза, } \\
\text { л на } \\
1000 \text { од. }\end{array}$ & $\begin{array}{c}\text { Кіль- } \\
\text { кість } \\
\text { плодів, }\end{array}$ & $\begin{array}{c}\text { Маса } \\
\text { плода, г }\end{array}$ & $\begin{array}{c}\text { Діаметр плода, } \\
\text { см }\end{array}$ & $\begin{array}{c}\text { Висота ро- } \\
\text { слини, см }\end{array}$ \\
\hline \multirow{4}{*}{$\begin{array}{c}\text { Без застосування } \\
\text { препарату (К) }\end{array}$} & - & $4 \pm 0,7$ & $80 \pm 0,7$ & $6,5 \pm 0,1$ & $35 \pm 0,7$ \\
\cline { 2 - 7 } & Меланоріз & 0,5 & $4 \pm 0,6$ & $160 \pm 0,8$ & $6,0 \pm 0,7$ & $40 \pm 1,0$ \\
\cline { 2 - 7 } & Меланоріз & 1,0 & $3 \pm 0,6$ & $190 \pm 0,7$ & $7,0 \pm 0,1$ & $54 \pm 0,6$ \\
\cline { 2 - 7 } & Мікофренд & 0,5 & $4 \pm 0,1$ & $95 \pm 0,7$ & $5,0 \pm 0,1$ & $30 \pm 0,7$ \\
\cline { 2 - 7 } & Мікофренд & 1,0 & $2 \pm 0,4$ & $120 \pm 0,8$ & $4,5 \pm 0,1$ & $38 \pm 0,7$ \\
\hline \multirow{3}{*}{.0} & $\begin{array}{l}\text { Без застосування } \\
\text { препарату (К) }\end{array}$ & - & $3 \pm 0,5$ & $80 \pm 0,7$ & $5,5 \pm 0.1$ & $37 \pm 0,7$ \\
\cline { 2 - 7 } & Меланоріз & 0,5 & $4 \pm 0,6$ & $150 \pm 0,5$ & $7,5 \pm 0,2$ & $47 \pm 0,9$ \\
\cline { 2 - 7 } & Меланоріз & 1,0 & $3 \pm 0,6$ & $170 \pm 0,8$ & $6,5 \pm 0,1$ & $25 \pm 0,8$ \\
\cline { 2 - 7 } & Мікофренд & 0,5 & $3 \pm 0,5$ & $75 \pm 0,8$ & $5,0 \pm 0,1$ & $24 \pm 0,24$ \\
\cline { 2 - 7 } & Мікофренд & 1,0 & $4 \pm 0,7$ & $110 \pm 0,8$ & $7,0 \pm 0,2$ & $22 \pm 0,8$ \\
\hline
\end{tabular}

(К) - контроль

Маса плода перцю солодкого також змінювалася залежно від дози препарату й коливалася від 75 до 190 г. За використання Меланорізу дозою 0,5 чи 1,0 л на 1000 од. розсади, під час вирощування гібрида Нікіта $\mathrm{F}_{1}$ чи сорту Клаудіо маса плода була найбільшою й становила 160-190 г (у випадку гібрида Нікіта $\mathrm{F}_{1}$ ) та 150-170 г (у випадку сорту Клаудіо). У вказаних варіантах перевищення до контролю склало 80-90 г та 70-110 г відповідно. У варіанті із застосуванням Мікофренду маса плода також була більшою за контрольний варіант, проте поступалася величиною за варіант із застосуванням Меланорізу. Діаметр плода від застосування мікоризних препаратів варіював у досить широких межах: від 4,5 см до 7,0 см. Найбільшим його значенням характеризувалися рослини сорту Клаудіо за використання Меланорізу дозою 0,5 л на 1000 од. розсади чи Мікофренду дозою 1,0 л на 1000 од. розсади. У вказаних варіантах діаметр плода становив 7,5 cм та 7,0 cм що перевищувало показник контрольного варіанта на 2,0 см та 1,5 см відповідно. Одночасно від замочування кореневої системи гібрида Нiкіта $F_{1}$ розчином Меланорізу дозою 1,0 л на 1000 од. розсади діаметр плода перевищував показник контролю на 7\%. В інших варіантах досліду не встановлено істотного збільшення досліджуваного показника.

Найвищими в досліді були рослини гібрида Нікіта $F_{1}$. Від застосування Меланорізу дозою 0,5-1,0 л на 1000 од. розсади висота рослин становила 40-54 см і перевищувала показник контрольного варіанта на 15-19 см. За використання Меланорізу дозою 0,5 л на 1000 од. розсади рослини сорту Клаудіо також перевищували показник рослин контрольного варіанта на 10 см. В інших варіантах досліду не встановлено впливу досліджуваних препаратів на збільшення показників біометрії: вони або поступалися, або знаходилися майже на однаковому рівні $з$ контролем.

Урожайність перцю солодкого в середньому коливалася від 0,9 до 2,5 кг/ $\mathrm{m}^{2}$. Досліджувані рослини не однаково реагували на обробку кореневої системи препаратами. Більшою врожайністю характеризувався гібрид Нікіта $\mathrm{F}_{1}$, а меншою - сорт Клаудіо. Під час вирощування гібрида Нікіта $\mathrm{F}_{1}$ та при використанні Меланорізу дозою 1,0 та 0,5 л на 1000 од. розсади врожайність була найвищою і становила 2,22,5 кг/ $\mathrm{m}^{2}$, що перевищувало показник контрольного варіанта на 0,9-1,2 кг/м² відповідно. Застосування Мікофренду у різних дозах за вирощування вказаного гібрида не сприяло суттєвому збільшенню врожайності. Величина вро- 
жайності складала лише $1,4-1,5$ кг/м² вищувало величину контрольного варіанта тільки на 8-15\%.

Найвищою врожайністю під час вирощування сорту Клаудіо, характеризувалися варіанти, де застосовували Меланоріз дозою 0,5-1,0 л на 1000 од. розсади та Мікофренд дозою 1,0 л на 1000 од. розсади. У вказаних варіантах урожай- ність за роки вирощування перцю солодкого становила 1,6-1,7 кг/ $\mathrm{m}^{2}$ і перевищувала показник контрольного варіанта на 60-70\%. Застосування Мікофренду дозою 0,5 л на 1000 од. розсади не сприяло збільшенню загальної врожайності. Зазначена доза препарату забезпечила отримання врожайності на рівні 0,9 кг/ $\mathrm{m}^{2}$, що знизило врожайність на $10 \%$ (табл. 2).

Таблиця 2 - Урожайність перцю солодкого у плівковій теплиці за використання мікоризних біопрепаратів, кг $/ \mathrm{M}^{2}$

\begin{tabular}{|c|c|c|c|c|c|c|c|c|}
\hline \multirow{2}{*}{ ì } & \multirow{2}{*}{ Біопрепарат } & \multirow{2}{*}{$\begin{array}{c}\text { Доза, л } \\
\text { на } 1000 \\
\text { од. роз- } \\
\text { сади }\end{array}$} & \multicolumn{2}{|c|}{ 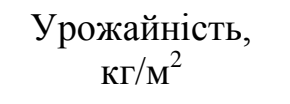 } & \multirow{2}{*}{$\begin{array}{c}\text { Середнє, } \\
2{ }^{2} / \mathbf{M}\end{array}$} & \multicolumn{2}{|c|}{ 土 до контролю } & \multirow{2}{*}{$\begin{array}{c}\text { Товар- } \\
\text { ність, } \\
\%\end{array}$} \\
\hline & & & 2018 p. & 2019 p. & & кг/м ${ }^{2}$ & $\%$ & \\
\hline \multirow{5}{*}{$\cdot \sqrt[T]{\widetilde{E}}$} & $\begin{array}{c}\text { Без застосування } \\
\text { препарату (К) }\end{array}$ & - & 1,2 & 1,4 & 1,3 & - & - & 87 \\
\hline & Меланоріз & 0,5 & 2,3 & 2,7 & 2,5 & $+1,2$ & +92 & 92 \\
\hline & Меланоріз & 1,0 & 2,2 & 2,2 & 2,2 & $+0,9$ & +69 & 94 \\
\hline & Мікофренд & 0,5 & 1,4 & 1,6 & 1,5 & $+0,2$ & +15 & 90 \\
\hline & Мікофренд & 1,0 & 1,3 & 1,5 & 1,4 & $+0,1$ & +8 & 89 \\
\hline \multirow{6}{*}{ 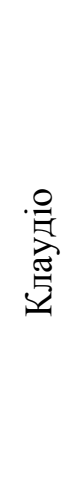 } & $\begin{array}{c}\text { Без застосування } \\
\text { препарату (К) }\end{array}$ & - & 0,9 & 1,1 & 1,0 & - & - & 88 \\
\hline & Меланоріз & 0,5 & 1,5 & 1,7 & 1,6 & $+0,6$ & +60 & 95 \\
\hline & Меланоріз & 1,0 & 1,6 & 1,8 & 1,7 & $+0,7$ & +70 & 94 \\
\hline & Мікофренд & 0,5 & 0,8 & 1,0 & 0,9 & $-0,1$ & -10 & 89 \\
\hline & Мікофренд & 1,0 & 1,5 & 1,8 & 1,6 & $+0,6$ & +60 & 95 \\
\hline & $\mathrm{HIP}_{05}$ & & 0,3 & 0,4 & & & & \\
\hline
\end{tabular}

Аналіз товарності продукції визначив ефективність застосування мікоризоутворюючих препаратів. Показник товарності знаходився на досить високому рівні й коливався від $87 \%$ до $95 \%$. Використання вказаних біопрепаратів сприяло отриманню високої товарності перцю солодкого, незалежно від дози препарату та сорту. Усі досліджувані варіанти характеризувалися високим значенням товарності, що значно перевищувало величину товарності контрольного варіанта.

Економічні показники від застосування різних доз мікоризних препаратів також мали змінний характер і залежали від їх дозування. У результаті вирощування гібрида Нікіта $\mathrm{F}_{1} \mathrm{i}$ використання Меланорізу дозою 0,5 та 1,0 л на 1000 од. розсади умовно чистий прибуток був найбільшим i становив 61-62,5 грн/м², що перевищувало показник контрольного варіанта у 2,5-2,7 раза. Таке значення прибутку забезпечило отримання високого рівня рентабельності - 98-101\%. Застосування Мікофренду теж сприяло одержанню високих показників економічної ефективності, відносно контрольного варіанта, проте за величиною вони поступались показникам варіанта, де застосовували Меланоріз.

Висновки. 1. Мікоризні препарати Мелано- 
piз та Мекофренд компанії БТУ-центр позитивно впливають на ростові процеси кореневої системи, яку повністю опановує міцелій гриба, формуючи при цьому ектомікоризу, що захищає її від перезволоження грунту та розвитку гнилей, особливо кореневої. Замочування кореневої системи розсади перед висаджуванням Меланорізом дозою 1,0 л на 1000 од. розсади чи Мікофрендом дозою 1,0 л на 1000 од. розсади під час вирощування гібрида Нікіта $\mathrm{F}_{1}$ забезпечує ранню бутонізацію, цвітіння та плодоношення на 2 доби, а по сорту Клаудіо на 3-5 діб. 2. Найбільшу кількість плодів отримано від використання Меланорізу дозою 0,5 л чи Мікофренду дозою 1,0 л на 1000 од. розсади під час вирощування сорту Клаудіо, де загальна кількість плодів збільшилася на 33 \%. Маса плода перцю солодкого змінюється залежно від дози та виду препарату й коливається від 75 г до 190 г. Від використання Меланорізу й дози препарату 0,5 чи 1,0 л на 1000 од. розсади під час вирощування гібрида Нікіта $\mathrm{F}_{1}$ чи сорту Клаудіо маса була найбільшою й становила 150-190 г. 3. Більшим значенням діаметра плода характеризувалися рослини сорту Клаудіо за замочування кореневої системи розчином Меланорізу дозою 0,5 л чи розчином Мікофренду дозою 1,0 л на 1000 од. розсади, а найвищими були рослини гібрида Нікіта $\mathrm{F}_{1}$ за використання Меланорізу дозою 0,5-1,0 л на 1000 од. розсади. 4. За використання мікоризоутворюючих препаратів Меланоріз чи Мікофренд урожайність перцю солодкого може збільшуватися до

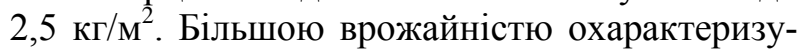
валися рослини гібрида Нікіта $F_{1}$, а меншою сорту Коаудіо. Використання Меланорізу дозою 0,5 та 1,0 л на 1000 од. розсади забезпечує

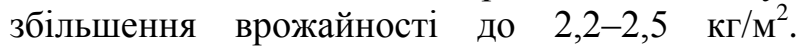
5. Мікоризоутворюючі препарати сприяють отриманню високої товарності незалежно від дози препарату та сорту, а саме: від 87 \% до 95 $\%$. За вирощування гібрида Нікіта $\mathrm{F}_{1}$ і використання Меланорізу дозою 0,5 та 1,0 л на 1000 од. розсади умовно чистий прибуток $є$ найбільшим і становить 61-62,5 грн/м², що сприяс отриманню рентабельності на рівні 98-101\%.

\section{References}

Anishyn, L.A. (2004). Vitchyzniani biolohichno aktyvni preparaty prosiatsia na polia Ukrainy [Domestic biologically active drugs are requested in the fields of Ukraine]. Propozytsiia, № 10, pp. 48-50 [in Ukrainian].
Antoniak, H.L., Kalynets-Mamchur, Z.I., Dudka, I.O. at al. (2013). Ekolohiia hrybiv [Mushroom ecology]. LNU imeni Ivana Franka (Seriia «Biolohichni Studii»). ISBN 978-617-100050-6 [in Ukrainian].

Barabash, O.Y. (2002). Rozsada ovochevykh kultur dlia vidkrytoho i zakrytoho gruntu [Vegetable seedlings for open and closed soil]. Kyiv: Vyshcha shkola [in Ukrainian].

Didovska, T.P. (2008). Vplyv humativ na yakisni pokaznyky vrozhaiu ovochevykh kultur [Influence of humates on yield quality indicators].Visnyk ahrarnoi nauky. № 9, II, pp. 95100 [in Ukrainian].

Dospekhov, B.A. (1985) Metodika polevogo opyta (s osnovami statisticheskoi obrabotki rezultatov issledovaniy) [Field experiment methodology (with the basics of statistical processing of research results)]. Moscow: Ahropromizdat [in Russian].

Dudnyk S.P., Yelahin, V.D., Odnolko, I.V. (1989) Perets i baklazhany [Peppers and eggplants]. Kyiv: Urozhai [in Ukrainian]

Frank, A.B. (1885). Ueber die auf Wurzelsymbiose beruhende Ernährung gewisser Bäume durch unterirdische Pilze. ABer. Dtsch. Bot. Ges. 3, pp. 128-145. [in English].

Ermolenko, O.V., Nerodenko, O.M., Lykhomanenko, H.A. at al. (2008). Bolezny i vrediteli ovoshchnykh kultur [Diseases and pests of vegetables]. Kyiv: Yunyvest medya [in Russian].

Heckman, D.S. et al. (2001) «Molecular evidence for the early colonization of land by fungi and plants». Science 293, pp. 1129-1133 [in English]

Hil, L.S., Pashkovskyi, A.I, Sulima, L.T. (2008). Suchasni tekhnolohii ovochivnytstva zakrytoho i vidkrytoho gruntu [Modern technologies of indoor and outdoor vegetable growing]. Ch.1. Zakrytyi grunt. Navchalnyi posibnyk. Vinnytsia: Nova knyha. [in Ukrainian].

Kamieński (1882). Les organes végétatifs de Monotropa hypopitys L.. Mémoires de la Société nat. des Sciences naturelles et mathém. de Cherbourg [in English].

Kostikov, I.Y., Dzhahan, V.V., Demchenko, E.M. at al. (2004). Botanika. Vodorosti ta hryby [Botany. Algae and mushrooms]. Kyiv [in Ukrainian].

Molina, R., Massicotte, H., \& Trappe, J.M. (1992). Specificity phenomena in mycorrhizal symbioses: community-ecological consequences and practical implications. Mycorrhizal function- 
ing: an integrative plant-fungal process, 357 [in English].

Nechytailo, V.A., Kucheriava, L.F. (2001). Botanika. Vyshchi roslyny [Botany. Higher plants]. Kyiv, Fitosotsiotsentr [in Ukrainian].

Perets solodkyi svizhyi Tekhnichni umovy [Fresh sweet pepper Specifications]: DSTU 324695. [Chynnyi vid 1997-01 - 01]. Kyiv: Derzhstandart Ukrainy [in Ukrainian].

Pysarenko, V.M. (2000). Zakhyst roslyn: ekolohichno-obgruntovani systemy [Plant protection: environmentally sound systems]. Poltava: Kamelot. [in Ukrainian].

Redecker, D. et al. (2000) «Glomalean fungi from the Ordovician». Science 289, pp. 1920-1921 [in English].

Schüßler, A. et al. (December 2001). A new fungal phlyum, the Glomeromycota: phylogeny and evolution.. Mycological Research 105 (12): 1413-1421. doi:10.1017/S0953756201005196 [in English].

Smyt, S.E., Ryd, D.Dzh. (2012). Mykoryznyi simbioz [Mycorrhizal symbiosis]. Per. s 3-go angl. yzdanyia E.Y. Voronynoi. Moscow: Tovaryshchestvo nauchnykh izdaniy KMK [in Russian].
Taylor, T.N. et al. (1995) «Fossil arbuscularmycorrhizae from the Early Devonian». Mycologia 87, pp. 560-573 [in English].

Tykhonenko, D.H., Dehtiarov, V.V. at al. (2003). Heolohiia z osnovamy mineralohii [Geology with the basics of mineralogy]. Navch. posibnyk. Kyiv: Vyshcha osvita [in Ukrainian].

Vdovenko, S.A. (2016). Efektyvnist vykorystannia biopreparatu pid chas vyroshchuvannia pomidora $\mathrm{u}$ vidkrytomu grunti rozsadnymy [Efficiency of use of biological preparation during growing tomatoes in open soil seedlings]. Visnyk Lvivskoho natsionalnoho ahrarnoho universytetu. Seriia «Ahronomiia»Lviv, № 20, pp. 66-73 [in Ukrainian].

Vdovenko, S.A. Davymoka, O.V., Mudrytska, L.M. (2016). Efektyvnist zastosuvannia deiakykh biopreparativ na produktyvnist tsybuli-porei [The effectiveness of the use of some biological products on the productivity of leeks]. Visnyk Zhytomyrskoho natsionalnoho ahroekolohichnoho universytetu. Zhytomyr, № 2 (56), T.1, pp. 108113 [in Ukrainian]. 